\title{
ПСИХОЛОГІЧНІ ОСОБЛИВОСТІ РОЗВИТКУ КОМПОНЕНТІВ СУВЕРЕННИХ МОРАЛЬНИХ ЦІННОСТЕЙ МАЙБУТНІХ ПСИХОЛОГІВ
}

УДК: 378.015.31:17.022.1

\section{Педоренко Валентина Миколаӥвна}

\begin{abstract}
Асистент кафедри психології та соиіальноі роботи Навчально-наукового інституту педагогіки, психології, підготовки фахівиів вищої кваліфікації Вінницького державного педагогічного університету імені Михайла Коцюбинського, м. Вінниия (Україна)
\end{abstract}

\begin{abstract}
Анотація. В статті розкривається зміст поняття суверенних моральних ијінностей майбутніх психологів як стійких, особистісно значущих, смисложиттєвих моральних утворень: взіриів, понять, установок, які дають можливість людині самостійно оцінювати власне життя та життя інших людей, описано зміст їх структурних компонентів: мотиваційно-потребового, когнітивного, поведінкового, рефлексивного. На основі застосування методу експертних оцінок визначено критерії виокремлення рівнів їх розвитку. Кількісний та якісний аналіз результатів емпіричного дослідження дав можливість виділити високий, середній та низький рівні розвитку структурних компонентів суверенних моральних цінностей майбутніх психологів. Автором описано прояви різних рівнів їх розвитку, а також досліджено та проаналізовано особливості розвитку компонентів суверенних моральних цінностей майбутніх психологів різних курсів навчання та успішних практикуючих психологів, зроблено порівняльний аналіз особливостей їх розвитку.
\end{abstract}

Автором статті розкривається зміст мотиваційно-потребового компоненту суверенних моральних ичінностей майбутніх психологів, який передбачає наявність в особистості потреб, які зумовлюють певні мотиви (інтереси, бажання), обумовлюють конкретну мету розвитку стійких, автономних, незалежних моральних цінностей майбутнього психолога; зміст когнітивного компоненту полягає у наявності знань, уявлень людини про власні моральні цүінності, переконання, їх доцільність та раціональність. Поведінковий компонент суверенних моральних цінностей психолога передбачає прояв в усіх сферах його життєдіяльності стійких, автономних, незалежних від зовнішніх обставин моральних цүінностей: прояв незалежності, свободи, здатність до саморозкриття, постійна робота над самим собою, пошук шляхів для самовдосконалення і самореалізації, захист власної честі, гідності, отримання задоволення від 


\begin{abstract}
справи, якою займається. Рефлексивний компонент передбачає усвідомлення майбутнім психологом того, як його сприймають $і$ оцінюють оточуючі, здатність аналізувати, переосмислювати власні моральні знання, почуття, переконання, ідеали, поведінку, сприяє успішному засвоєнню, розширенню і перетворенню сочіального досвіду, перекладу зовнішнього соціального у внутрішній план.
\end{abstract}

Ключові слова: суверенні моральні иінності, компоненти суверенних моральних цุінностей, мотиваціийно-потребовий, когнітивний, поведінковий, рефлексивний компоненти, прагнення до самоактуалізації, автономність, креативність, спонтанність.

Постановка проблеми у загальному вигляді та її звя'зок із важливими науковими чи практичними завданнями. Особистісне та професійне становлення майбутніх психологів відбувається в умовах складної трансформації ідеалів і цінностей суспільства: на зміну колективізму, патріотизму, гостинності і толерантності приходять, у певній мірі, індивідуалізм, егоїзм, прагнення до збагачення, дещо більш байдуже ставлення до оточуючих. В період постійних соціально-економічних змін суспільство найбільше потребує суверенних, незалежних особистостей, які здатні відчувати екзистенційну впевненість (свободу, осмисленість, цінності власного буття), творчо ставитись до власного життя, бути критичним до ідеологічних впливів, відчувати особистісну відповідальність, здатність до самостійного прийняття рішень, реалізації власних планів, відстоювання власної моральної позиціï.

Аналіз останніх досліджень і публікацій, в яких започатковано розв'язання даної проблеми і на які спирається автор. Багато учених наголошували на існуванні особливого виду особистісних цінностей. Так,
А. Адлер звертав увагу на унікальність ціннісної системи особистості [1], Е. Еріксон наголошував на важливості процесу автономії у становленні морального «Я» та формуванні власної системи моральних цінностей [3], М. Рокич називав особистісні цінності найбільш значущими, які залежать від потреб людини [10], Д. О. Леонтьєв серед особистісних цінностей виділяє вищі, називаючи їх смисложиттєвими орієнтаціями [5], І. Д. Бех виділяє особливий вид особистісних цінностей і називає їх усвідомленими узагальненими самовартісними смисловими утвореннями особистості [2], 3. С. Карпенко серед форм репрезентації цінностей виділяє особистісні як стійку мотиваційну структуру особистості, що є внутрішніми носіями соціальної регуляції [4], A. А. Фурман досліджує ціннісноорієнтаційну сферу особистості, як взаємодоповнення вартісно-орієнтувального, нормативно-регуляційного, суспільно-морального і духовно-естетичного компонентів [9].

Протягом останніх років науковцями часто аналізується проблема психологічного здоров'я особистості, яке забезпечує психологічну адаптацію людини в суспільстві, сприяє 
iii самореалізації, підвищенню якості життя, здійснює психологічну допомогу при завершенні життєвого шляху. Сформованість власних, суверенних моральних цінностей особистості є ознакою психологічного здоров'я людини. Оскільки психологічно здорова людина, як правило, є спонтанною, творчою, життєрадісною, відкритою до пізнання себе і навколишнього світу не тільки розумом, а і відчуттями, інтуїцією. Така особистість повністю приймає себе, постійно займається саморозвитком, визнає цінність і унікальність інших, покладає відповідальність за власне життя на саму себе. Її життя наповнене сенсом.

До цього часу виокремлення суверенних моральних цінностей в окремий їх вид та дослідження структурних компонентів ще не було зроблено.

Метою статті $\epsilon$ виокремлення та дослідження особливостей розвитку структурних компонентів суверенних моральних цінностей майбутніх психологів.

Виклад основного матеріалу дослідження 3 повним обгрунтуванням отриманих наукових результатів. Суверенними моральними цінностями (далі СМЦ) ми називаємо стійкі, особистісно значущі, смисложиттєві моральні утворення (взірці, поняття, установки), що уможливлюють здійснення людиною самооцінки власного життя та буденність інших. Зроблений нами теоретичний аналіз наукових досліджень 3 проблеми розвитку власних моральних цінностей дозволив нам виок- ремити такі складові компоненти СМЦ майбутніх психологів: мотиваційно-потребовий, когнітивний, поведінковий та рефлексивний.

Мотиваційно-потребовий компонент СМЦ майбутніх психологів передбачає наявність в особистості потреб, які зумовлюють певні мотиви (інтереси, бажання), обумовлюють конкретну мету розвитку стійких, автономних, незалежних моральних цінностей майбутнього психолога (розвиток себе як професіонала, прагнення до самореалізації, самоактуалізації, потреба у постійному самовдосконаленні, прагнення до ідентичності, до пізнання себе і світу загалом та ін.). Отже, основою будь-якої діяльності є мотивація, тому ми вважаємо, що мотиваційно-потребова складова $€$ базою формування СМЦ майбутніх психологів. Особливої уваги заслуговує потреба особистості в самоактуалізації, яка передбачає прагнення людини до якнайповнішого виявлення і розвитку своїх особистісних можливостей.

Як і будь-яка активність людини починається із виникнення в людини відповідних спонук, так і розвиток СМЦ майбутніх психологів починається з виникнення в людини відповідних потреб. Дослідники виокремлюють у становленні СМЦ людини розвиток іï потреб від нижчих до вищих, завдяки чому відбувається трансформація свідомості та самосвідомості [5]. Проте навіть біологічні потреби у їжі, безпеці тощо вже не є у людини суто біологічними, адже людині властиво задовольня- 
ти їх соціальним, культурним способом. Часто трапляються випадки, коли людина відмовляється від задоволення біологічних потреб заради морально-духовних. Формування СМЦ майбутніх психологів може спонукатися різними мотивами (наприклад, самоактуалізації, розвитку себе як професіонала та ін.). Уявлення кінцевого результату діяльності відображається через мету. Зазначимо, що розвиток СМЦ майбутніх психологів є метою вищого рівня узагальнення, він утворює абстрактну мету - уявлення про певний принцип, ідеал, заради якого здійснюється цей процес.

На жаль, у сучасних соціальноекономічних умовах проблема розвитку особистості, реалізації іiі потреби в самоактуалізації відступає на другий план, найактуальнішим для багатьох категорій населення стає задоволення потреб нижчих рівнів. Тому одним із найголовніших завдань сучасного освітнього процесу є розвиток високої моральності підростаючого покоління. Будь-яке суспільство потребує високодуховних громадян, здатних самостійно мислити та діяти задля суспільного блага.

Кількісний та якісний аналіз результатів емпіричного дослідження, у якому взяли участь 235 майбутніх психологів Вінницького державного педагогічного університету імені Михайла Коцюбинського та 98 практикуючих психологів м. Вінниці та Вінницької області, дав нам можливість виділити такі рівні розвитку мотиваційно-потребового компоненту
СМЦ майбутніх психологів: низький, середній та високий. Критеріями виокремлення таких рівнів розвитку мотиваційно-потребової складової СМЦ, на думку незалежних експертів, є наступні: вираженість потреби в самоактуалізації, прагнення до самореалізації (бажання майбутніх психологів до якнайповнішого виявлення і розвитку своїх особистісних можливостей, прагнення до реалізації у професійній діяльності власних потенційних можливостей, здібностей, покликань), сформованість морального ідеалу, прагнення до досягнення успіху в цілому.

Високий рівень розвитку мотиваційнопотребового компоненту СМЦ майбутніх психологів передбачає: значну перевагу вираженості прагнення до самоактуалізації, прагнення до самореалізації порівняно 3 іншими мотивами соціально-психологічної активності майбутніх психологів, бажання реалізувати свій професіоналізм, досягнути високих результатів у професійній діяльності, прагнення отримувати задоволення від виконання складних завдань, які дають можливість особистісного розвитку, усвідомлення власного морального ідеалу.

Середній рівень розвитку мотиваційнопотребового компоненту СМЦ майбутніх психологів характеризується частковою вираженістю прагнення досліджуваних до самореалізації поряд із вираженими іншими особистісними потребами: у безпеці, у міжособистісних стосунках, повазі (потреба у самореалізації 
знаходиться у зоні часткового задоволення), розмитість образу власного морального ідеалу.

Низький рівень мотиваційнопотребового компоненту СМЦ майбутніх психологів характерний для досліджуваних, у яких потреба у самореалізації не виражена, сформованість морального ідеалу недостатня. Актуальними для них є інші види потреб: потреба у безпеці, прагнення до групового визнання і поваги. Дані рівні критерію брались до уваги, оцінювались при проведенні констатувального експерименту.

Узагальнені результати дослідження мотиваційно-потребового компоненту СМЦ майбутніх психологів та успішних практикуючих психологів представлені нами в табл. 1. На основі аналізу емпіричних даних встановлено, що у 48,5\% майбутніх психологів різних курсів мотиваційно-потребовий компонент сформований на високому рівні, у 30,6\% досліджуваних він сформований на середньому рівні, у 20,9\% досліджуваних даний компонент сформований на низькому рівні (див. табл. 1).

Особливо варто відмітити, що для біль- шої частини $(62,5 \%)$ досліджуваних студентівмагістрів майбутніх психологів характерним $€$ високий рівень мотиваційно-потребового компоненту СМЦ, що засвідчує про наявність у них високого прагнення до самоактуалізації, самовдосконалення, реалізації себе як майбутнього професіонала.

Результати дослідження мотиваційнопотребового компоненту СМЦ практикуючих психологів суттєво відрізняються від результатів майбутніх психологів (табл.1). Зокрема, низький рівень характерний тільки 10,2\% досліджуваних практикуючих психологів. Однак показник у них високого рівня розвитку даного компоненту є дещо нижчим від показника студентів магістрів (62,5\% і 55,1\%).

Методами математичної статистики (tкритерій Ст'юдента для незалежних вибірок) за допомогою програми SPSS Statistics 22 доведено існування відмінностей у показниках поведінкового компоненту СМЦ студентівпсихологів I, II курсів та успішних практикуючих психологів: $\mathrm{t}$ емп. $=3,166$, при $\mathrm{p} \leq 0,05$. Відмінностей у показниках мотиваційнопотребового компоненту СМЦ студентівпсихологів IV курсу і студентів магістрів та

Таблиия 1.

Рівень розвитку мотиваційно-потребового компоненту СМЦ у майбутніх психологів різних курсів та практикуючих психологів

\begin{tabular}{|c|l|c|c|c|c|c|c|c|}
\hline $\begin{array}{c}\text { № 3/ } \\
\Pi\end{array}$ & $\begin{array}{c}\text { Рівень розвитку моти- } \\
\text { ваційно-потребового } \\
\text { компоненту СМЦ }\end{array}$ & $\begin{array}{c}\text { I курс } \\
\text { у \% }\end{array}$ & $\begin{array}{c}\text { II } \\
\text { курс } \\
\text { y \% }\end{array}$ & $\begin{array}{c}\text { III } \\
\text { курс у } \\
\%\end{array}$ & $\begin{array}{c}\text { IV } \\
\text { курс } \\
\text { y }\end{array}$ & $\begin{array}{c}\text { Магістри у } \\
\%\end{array}$ & $\begin{array}{c}\text { Студенти- } \\
\text { психологи } \\
\text { всього } \\
\text { (у \%) }\end{array}$ & $\begin{array}{c}\text { Практику-ючі } \\
\text { психологи } \\
\text { (у \%) }\end{array}$ \\
\hline 1 & Високий & 36,4 & 39,7 & 52,4 & 60,0 & 62,5 & 48,5 & 55,1 \\
\hline 2 & Середній & 34,5 & 36,2 & 30,9 & 27,5 & 20,0 & 30,6 & 34,7 \\
\hline 3 & Низький & 29,1 & 24,1 & 16,7 & 12,5 & 17,5 & 20,9 & 10,2 \\
\hline
\end{tabular}


показниками практикуючих психологів методами математичної статистики не виявлено. Отже, як бачимо 3 результатів емпіричного дослідження, майже половині досліджуваних студентів-психологів (48,5\%) властивий високий рівень розвитку мотиваційно-потребового компоненту СМЦ, що свідчить про їх прагнення до самоактуалізації.

Когнітивний компонент СМЦ полягає у наявності знань, уявлень людини про власні моральні цінності, переконання, їх доцільність та раціональність. Багатьма науковцями $[6 ; 7]$ висловлюється думка про те, що особистісні моральні цінності $є$ похідними від суспільних цінностей, вони завжди мають бути усвідомлені людиною. Когнітивний компонент СМЦ майбутніх психологів передбачає також i знання людини про цінності, ідеали суспільства, розуміння їх значення і сенсу для свого професійного розвитку. Основними елементами когнітивного компоненту СМЦ є знання про загальносуспільні і власні моральні цінності, переконання, усвідомлення власного морального ідеалу.

Свідоме наслідування загальносуспільних цінностей $є$ достатньо значущимим у розвитку власної ціннісної системи. Однак тільки реально пережиті, вкорінені в структурі особистості моральні цінності, стають справжніми регуляторами поведінки людини.

Засвоєння особистістю моральних знань відбувається у кілька етапів, починаючи від простих відомостей про певні моральні цінності суспільства та особистості і закінчуючи вмінням співвіднести їх 3 власним «Я». При цьому до уваги беруться такі особливості моральних знань: їх об'єм, усвідомленість, міцність. Моральні переконання - це стійкі особистісні уявлення про моральні цілі, норми, ідеали, яких повинна дотримуватись особистість у поведінці. Моральні переконання виникають в результаті інтеріоризації моральних понять про ідеали, норми моралі. Моральні переконання відображають впевненість людини в істинності власної ціннісної системи.

Розвиток СМЦ майбутніх психологів сприяє наближенню особистості до зразка бажаного морального розвитку - морального ідеалу. Моральний ідеал є своєрідним орієнтиром людини для самовдосконалення, який наділений тими моральними якостями, які імпонують особистості. На основі морального ідеалу людина оцінює свою поведінку та поведінку інших людей.

Кількісний та якісний аналіз отриманих результатів дав нам можливість виділити три рівні розвитку когнітивного компоненту СМЦ майбутніх психологів: високий, середній та низький. На думку незалежних експертів, критеріями виділення рівнів розвитку когнітивного компоненту є: 1) наявність знань, уявлень про власні та загальносуспільні моральні цінності; 2) розуміння значення загальносуспільних моральних цінностей; 3) усвідомлення власних моральних цінностей та їх доцільності для здійснення професійної діяльності. 
Високий рівень розвитку когнітивного компоненту СМЦ майбутніх психологів передбачає: високий рівень розвитку моральних знань, глибоке розуміння змісту моральних понять, усвідомлення їх доцільності для здійснення професійної діяльності, чітке усвідомлення власних моральних цінностей, їх співвідношення із загальносуспільними. Середній рівень когнітивного компоненту СМЦ майбутніх психологів передбачає: середній рівень розвитку моральних знань, розуміння змісту більшості моральних понять, загальносуспільних моральних цінностей, їх доцільності для професійної діяльності, нечіткість розрізнення власних моральних цінностей від загальносуспільних. Низький рівень когнітивного компоненту СМЦ передбачає: низький рівень розвитку моральних знань, сформованості моральних переконань, неусвідомлене наслідування загальносуспільних моральних цінностей, невизначеність власних моральних цінностей, нерозуміння їх значущості для професійної діяльності.

Узагальнені результати дослідження когнітивного компоненту СМЦ майбутніх психологів представлені нами у табл. 2. Високий рівень розвитку когнітивного компоненту СМЦ характерний для 22,6\% майбутніх психологів, середній рівень - для 49,4\%, 28,0\% досліджуваних мають низький рівень. Отримані результати дослідження дали нам можливість зробити висновок про те, що тільки для четвертої частини досліджуваних майбутніх психологів характерним $є$ наявність моральних знань, уявлень, розуміння змісту моральних понять, чітке усвідомлення власних моральних цінностей, усвідомлення їх доцільності для здійснення професійної діяльності.

Для переважної більшості досліджуваних першокурсників $(49,4 \%)$ характерний середній рівень розвитку когнітивного компоненту СМЦ. Дані досліджувані розуміють зміст багатьох моральних понять, усвідомлюють загальносуспільні моральні цінності, їх значення для виконання психологом професійної діяльності, однак їм складно розмежувати власні моральні цінності від загальносуспільних. Слід відмітити суттєві відмінності за усіма рівнями розвитку когнітивного компоненту між показниками студентів психологів та

Рівень розвитку когнітивного компоненту

Таблиця 2.

СМЦ у майбутніх психологів різних курсів та практикуючих психологів

\begin{tabular}{|c|l|c|c|c|c|c|c|c|}
\hline $\begin{array}{c}\text { № } \\
3 / п\end{array}$ & $\begin{array}{c}\text { Рівень розвитку } \\
\text { когнітивного ком- } \\
\text { поненту СМЦ }\end{array}$ & $\begin{array}{c}\text { I курс } \\
\text { у } \%\end{array}$ & $\begin{array}{c}\text { II курс } \\
\text { у \% }\end{array}$ & $\begin{array}{c}\text { III курс } \\
\text { у } \%\end{array}$ & $\begin{array}{c}\text { IV курс } \\
\text { у } \%\end{array}$ & $\begin{array}{c}\text { Магістри } \\
\text { у } \%\end{array}$ & $\begin{array}{c}\text { Студенти } \\
\text { психологи } \\
\text { всього } \\
\text { (у \%) }\end{array}$ & $\begin{array}{c}\text { Практикуючі } \\
\text { психологи } \\
\text { (у \%) }\end{array}$ \\
\hline 1 & Високий & 18,2 & 20,7 & 23,8 & 25,0 & 27,5 & 22,6 & 52,0 \\
\hline 2 & Середній & 49,1 & 50,0 & 50,0 & 47,5 & 50,0 & 49,4 & 43,9 \\
\hline 3 & Низький & 32,7 & 29,3 & 26,2 & 27,5 & 22,5 & 28,0 & 4,1 \\
\hline
\end{tabular}


практикуючих психологів.

Як видно з табл. 2. у досліджуваних третього курсу помітним є збільшення їх кількості з високим рівнем розвитку когнітивного компоненту СМЦ $(23,8 \%)$ і відповідно зменшення їх кількості з низьким (26,2\%) та середнім рівнем (50,0\%). Для них є характерним підвищена увага до самого себе, до своїх потреб, інтересів, відповідно і до власних моральних цінностей (їх усвідомлення, обгрунтування їх доцільності при здійсненні професійної діяльності). Крім того, спостерігається зменшення кількості досліджуваних з низьким рівнем розвитку когнітивного компоненту СМЦ від першого курсу $(32,7 \%)$ до студентів магістрів (22,5\%). Однак велика кількість досліджуваних мають середній рівень розвитку когнітивного компоненту СМЦ (49,4\%), що свідчить про розмитість загальносуспільних i особистісних моральних цінностей, недостатню сформованість уявлень досліджуваних про власні моральні цінності. Серед загальносуспільних моральних цінностей найчастіше досліджувані називають чесність, щирість, доброта, відповідальність та ін. Серед власних моральних цінностей названо любов, здоров'я, сім'я, власна честь і гідність, робота та ін. Як бачимо, називаючи власні моральні цінності, майбутні психологи не називають ті, які прямо пов'язані з обраною професією. Звичайно, цей факт можна пояснити тим, що дівчата i хлопці в юнацькому віці хочуть бути щасливими, успішними, прагнуть досягти матеріа- льного добробуту, стабільності, шукають конкретної вигоди від діяльності, яку виконують. Однак, здобуваючи майбутню професію, їм варто також зосередитись і на власному розвитку як майбутнього фахівця. Крім того, зазначимо, що більшість досліджуваних стверджують, що не було ситуацій, коли їх власні моральні цінності суперечили загальносуспільним, що свідчить про орієнтацію в першу чергу на загальносуспільні моральні цінності, а не на власні.

Називаючи моральні якості психолога, майбутніми психологами найчастіше називаються такі: здатність співчувати, прийняття клієнта таким, який він $\epsilon$, чуйність, доброта, толерантність, водночас мало називаються такі якості, як професіоналізм, відповідальність, здатність до самоактуалізації і самовдосконалення себе як професіонала.

Варто звернути увагу також на те, що сучасні умови розвитку українського суспільства, його нестабільність, події, пов'язані 3 антитерористичною операцією на сході країни призводять до того, що молодим людям часто доводиться змінювати свої погляди на життя, на цінність деяких речей, а відповідно досить часто змінюються і особистісні переконання, ідеали, власні моральні цінності.

Поведінковий компонент СМЦ психолога передбачає прояв в усіх сферах його життєдіяльності стійких, автономних, незалежних від зовнішніх обставин моральних цінностей, які лежать в основі моральних вчинків, про- 
фесійних дій, моральних виборів: прояв незалежності, свободи, здатність до саморозкриття, постійна робота над самим собою, пошук шляхів для самовдосконалення і самореалізації, захист власної честі, гідності, отримання задоволення від справи, якою займається, розуміння іiі сенсу, здатність розуміти екзистенційну цінність життя «тут і тепер», прагнення до гармонійних стосунків $з$ людьми, віра в людей, в велику силу людських можливостей, творче ставлення до життя, прояв автономності, яка на думку Е. Фромма, є позитивною «свободою для» на відміну від негативної «свободи від» [8].

Незалежними експертами визначено такі критерії рівнів поведінкового компоненту СМЦ: 1) здатність до морального вибору та моральних вчинків; 2) рівень вираженості креативності, автономності, спонтанності, саморозуміння, аутосимпатії, гнучкості у спілкуванні, контактності; 3 ) прояви моральних вчинків та дій на основі власних моральних цінностей добра, справедливості, порядку, краси.

Поведінковий компонент СМЦ майбутніх психологів проявляється на трьох рівнях розвитку: високому, середньому та низькому.

Особистість 3 високим рівнем поведінкового компоненту СМЦ здатна приймати себе та інших як унікальних, неповторних, з власним потенціалом, здатна в поведінці бути самою собою, є чесною в своїх емоціях і почуттях, наділена глибокою вірою в себе та інших, підтверджує в діяльності, вчинках особистісні цінності, вільно виражає їх. Взаємодіючи 3 іншими, особистість здатна бути самостійною, незалежною, є більш компетентною в часі, орієнтована на життя в цілому, використовує минуле і майбутнє для того, щоб надати життю ще більшого сенсу, проявляє свободу від психологічного захисту, який відділяє особистість від самої себе.

Середній рівень розвитку поведінкового компоненту СМЦ майбутніх психологів передбачає середній рівень вираженості креативності, автономності, спонтанності, саморозуміння. Для студентів-психологів 3 середнім рівнем розвитку поведінкового компоненту СМЦ характерним є дотримання в діяльності цінностей добра, порядку, справедливості, здатність цінувати теперішнє, не відкладаючи на життя на «потім», проявляють віру в людей, в їх можливості, впевненість в собі.

Низький рівень розвитку поведінкового компоненту СМЦ майбутніх психологів передбачає низький рівень вираженості креативності, автономності, спонтанності, саморозуміння. Студенти-психологи 3 даним рівнем характеризуються низькою пізнавальною активністю, занурені в переживання минулого, часто демонструють стереотипність, негнучкість, нездатність відійти від зразка у вирішенні певних проблем, проявляють недовіру до людей, прагнуть ними маніпулювати, залежні від думки оточуючих про них.

Узагальнені результати дослідження поведінкового компоненту СМЦ майбутніх 
психологів та практикуючих психологів представлені нами у табл. 3. Зокрема, високий рівень поведінкового компоненту СМЦ притаманний тільки 20,9\% досліджуваних студентів психологів. Для них характерним є високі показники гнучкості у спілкуванні, що характеризує їх орієнтацію на особистісне спілкування, щирість, доброзичливість, уникнення маніпуляцій під час взаємодії з оточуючими, надання переваги цінностям самоактуалізованої особистості, таким як добро, справедливість, порядок, прояв незалежності, свободи, автономності, впевненості в собі.

Середній рівень поведінкового компоненту СМЦ студентів-психологів характерний для 32,8\% досліджуваних, які мають середні показники за шкалами креативності, гнучкості у спілкуванні, контактності. Це дає можливість охарактеризувати даних досліджуваних як таких, що відчувають цінності справедливості, добра, краси, порядку, однак інколи вони проявляють невпевненість, тривожність, орієнтуються на соціальні стереотипи, залежні від думки оточуючих про них.
Для більшості досліджуваних студентів психологів (46,3\%) характерний низький рівень поведінкового компоненту СМЦ. Для даних досліджуваних характерним є недовіра до людей, невпевненість в собі, схильність до маніпулювання іншими, низький рівень спонтанності, що свідчить про зосередженість на загальносуспільних цінностях.

Для більшості студентів-психологів першого та другого курсу характерний низький рівень поведінкової складової СМЦ (54,6\% і 50,0\%). Їм притаманні такі особливості: упередженість, недовіра до людей, нездатність до спонтанності через зосередженість на загальносуспільних цінностях, невпевненість у собі, тривожність, схильність орієнтуватись на стереотипи, закритість новому досвіду.

Як видно з таблиці 3, показники розвитку поведінкового компоненту СМЦ студентів психологів та практикуючих психологів суттєво відрізняються за усіма рівнями розвитку. За допомогою t-критерію Ст'юдента ми довели, що існують відмінності у показниках автономності студентів-психологів I, II курсів і успіш-

Таблиия 3.

Рівень розвитку поведінкового компоненту СМЦ майбутніх психологів різних курсів та практикуючих психологів

\begin{tabular}{|c|l|c|c|c|c|c|c|c|}
\hline $\begin{array}{c}\text { № } \\
\text { 3/п }\end{array}$ & $\begin{array}{c}\text { Рівень розвитку пове- } \\
\text { дінкового компоненту } \\
\text { СМЦ }\end{array}$ & $\begin{array}{c}\text { I курс } \\
\mathrm{y} \%\end{array}$ & $\begin{array}{c}\text { II курс } \\
\mathrm{y} \%\end{array}$ & $\begin{array}{c}\text { III курс } \\
\mathrm{y} \%\end{array}$ & $\begin{array}{c}\text { IV курс } \\
\mathrm{y} \%\end{array}$ & $\begin{array}{c}\text { Магістри } \\
\text { у \% }\end{array}$ & $\begin{array}{c}\text { Студенти } \\
\text { психологи } \\
\text { (у \%) }\end{array}$ & $\begin{array}{c}\text { Практи- } \\
\text { куючі } \\
\text { психоло- } \\
\text { ги } \\
\text { ( \%) }\end{array}$ \\
\hline 1 & Високий & 12,7 & 13,8 & 23,8 & 27,5 & 32,5 & 20,9 & 43,9 \\
\hline 2 & Середній & 32,8 & 36,2 & 33,4 & 30,0 & 30,0 & 32,8 & 44,9 \\
\hline 3 & Низький & 41,3 & 54,6 & 42,8 & 42,5 & 37,5 & 46,3 & 11,2 \\
\hline
\end{tabular}


них практикуючих психологів: $\mathrm{t}$ емп. $=4,884$, при $\mathrm{p} \leq 0,01 ; \mathrm{y}$ показниках креативності: $\mathrm{t}=6,031, \mathrm{p} \leq 0,01 ; \mathrm{y}$ показниках орієнтування в часі $\mathrm{t}$ емп. $=6,249, \mathrm{p} \leq 0,01$; за шкалою цінностей t емп. $=3,855, \mathrm{p} \leq 0,01$.

За допомогою U-критерію Манна-Уітні ми довели, що існують відмінності у показниках автономності студентів-психологів IV куpсу та магістратури $U$ емп. $=2821,0$, при $\mathrm{p} \leq 0,01 ;$ у показниках креативності $U$ емп. $=2872,5$, при $\mathrm{p} \leq 0,05$; у показниках орієнтування в часі $U$ емп. $=2905,0$, при $\mathrm{p} \leq 0,05$. За шкалою цінностей відмінностей у результатах студентів-психологів IV курсу та магістратури не виявлено.

Слід відмітити, що для досліджуваних усіх курсів характерними є низькі показники за шкалою автономності, саморозуміння, аутосимпатії, що свідчить про невпевненість у собі, тривожність, схильність підміняти власні смаки і оцінки зовнішніми соціальними стандартами.

Отже, серед досліджуваних різних курсів спостерігається досить мала їх кількість 3 високим рівнем розвитку автономності та креативності, що вказує на їх залежність від думки оточуючих про них, схильність довіряти стереотипам. Шкала цінностей представлена переважно високими балами, особливо серед студентів третього і четвертого курсів, що свідчить про те, що дані досліджувані сповідують цінності добра, краси, справедливості, порядку.
Рефлексивний компонент СМЦ передбачає усвідомлення майбутнім психологом того, як його сприймають і оцінюють оточуючі, здатність аналізувати, переосмислювати власні моральні знання, почуття, переконання, ідеали, поведінку, сприяє успішному засвоєнню, розширенню і перетворенню соціального досвіду, перекладу зовнішнього соціального у внутрішній план. Внаслідок такого аналізу і переосмислення своїх якостей, властивостей, характеристик, успіхів, невдач i їх причин особистість піднімається на більш високий рівень у самоактуалізації, самовдосконаленні.

Здатність до рефлексивності починає розвиватись в особистості починаючи з дошкільного віку через засвоєння загальносуспільних моральних цінностей, інтенсивне формування самооцінки, здатності розуміти свої почуття та інших людей. Однак саме в період юності відбувається розкриття особистістю свого неповторного внутрішнього світу, формування цілісного уявлення про себе. Такий вияв самосвідомості полягає в тому, що юнаки і юнки починають сприймати свої переживання, емоції не як відображення зовнішніх подій, а як стан свого внутрішнього Я, усвідомлюють свою неповторність, неподібність до інших. Під час вибору професії вони зважають не тільки на свої інтереси, а й на багато інших обставин, передусім порівнюють свої здібності, можливості з вимогами, які ставить до людини та чи інша професія. Цим зумовлений їх інтерес до різноманітних аспектів психо- 
логії саморозвитку.

Юнацький вік визначається багатьма вченими як сензитивний період для засвоєння моральних цінностей особистості. Саме в цьому віці відбувається інтенсивний розвиток рефлексії, відкриття свого «Я», усвідомлення власної індивідуальності і її властивостей, виникнення життєвих планів [7; 9]. На нашу думку, в цьому віці може інтенсивно розвиватись морально-професійна рефлексія.

O.В. Матласевич аналізуючи шляхи формування моральності особистості за Е. Гофманом, Л. Колбергом, стверджує, що найбільш ефективним шляхом формування моральних цінностей $є$ рефлексивний. Тобто, людина не може щось робити, не розуміючи сенсу, вона намагається розпізнати, з'ясувати, обгрунтувати свої дії і в результаті прийняти відповідне рішення [6].

За допомогою моральної рефлексії суспільні цінності можуть стати глибоко особистісними. Людина здатна аналізувати власну ціннісну систему, іiі сенс, а також ціннісну систему інших людей, що дає можливість для ідентифікації особистості, порівняння себе 3 бажаним моральним ідеалом та ін. Моральна рефлексія сприяє виникненню в людини внутрішньої бесіди із самим собою, внаслідок якої відбувається співвіднення «Я» реального та «Я» ідеального.

Незалежними експертами виокремлено наступні критерії виділення рівнів розвитку рефлексивного компоненту СМЦ майбутніх психологів: здатність до переосмислення особистісних моральних цінностей, їх доцільності, до збереження внутрішнього вільного простору; здатність до об'єктивного аналізу власної поведінки, незважаючи на емоції, бажання, наміри.

Рефлексивний компонент СМЦ майбутніх психологів проявляється на трьох рівнях розвитку: високому, середньому і низькому.

Високий рівень розвитку рефлексивного компоненту СМЦ студентів-психологів передбачає наявність у них високого рівня усвідомленості особистісних моральних цінностей, їх обгрунтованість, здатність орієнтуватись у вчинках на їх сенс, відчувати цінність, переживати захопленість цінністю, відчувати екзистенційну значущість того, що відбувається. Особистість з високим рівнем розвитку рефлексивного компонента здатна при потребі відкласти свої бажання, почуття, наміри для того, щоб подивитись на себе і ситуацію 3 певної дистанції, не орієнтуватись тільки на самого себе, а сприймати ситуацію, розмірковувати над нею, адекватно іï оцінювати. Для студентів-психологів з високим рівнем рефлексивного компоненту СМЦ характерним $є$ емоційно-ціннісне ставлення до світу, внутрішня і зовнішня осмисленість (життя заради когось або чогось).

Середній рівень розвитку рефлексивного компоненту СМЦ передбачає здатність аналізувати власні емоції, почуття, професійні уміння, розмірковувати над ситуацією, об’- 
єктивно аналізувати іiі причинно-наслідкові зв'язки.

Низький рівень розвитку рефлексивного компоненту СМЦ майбутніх психологів свідчить про зосередженість майбутнього психолога переважно на самому собі, низьким рівнем здатності до аналізу, переосмис- показниках рефлективності студентівпсихологів I, II курсів та успішних практикуючих психологів ( $\mathrm{t}$ емп. $=8,611$, при $\mathrm{p} \leq 0,01$ ), за допомогою U-критерію Манна-Уітні доведено, що існують відмінності у показниках рефлективності студентів-психологів IV курсу і студентів-магістрів та показниками успішних

Таблиия 4.

Рівень розвитку рефлексивного компоненту

\section{СМЦ у майбутніх психологів різних курсів та практикуючих психологів}

\begin{tabular}{|c|l|c|c|c|c|c|c|c|}
\hline $\begin{array}{c}\text { № } \\
3 / \Pi\end{array}$ & $\begin{array}{c}\text { Рівень розвитку } \\
\text { рефлексивного } \\
\text { компоненту СМЦ }\end{array}$ & $\begin{array}{c}\text { I курс } \\
\text { у \% }\end{array}$ & $\begin{array}{c}\text { II курс } \\
\text { у \% }\end{array}$ & $\begin{array}{c}\text { III курс } \\
\text { у \% }\end{array}$ & $\begin{array}{c}\text { IV } \\
\text { курс } \\
\text { \% }\end{array}$ & $\begin{array}{c}\text { Студенти } \\
\text { магістри } \\
\text { у \% }\end{array}$ & $\begin{array}{c}\text { Студенти } \\
\text { психологи } \\
\text { у \% }\end{array}$ & $\begin{array}{c}\text { Практикуючі } \\
\text { психологи у } \\
\%\end{array}$ \\
\hline 1 & Високий & 10,9 & 8,6 & 23,8 & 25,0 & 27,5 & 17,8 & 42,9 \\
\hline 2 & Середній & 29,1 & 34,6 & 35,7 & 35,0 & 35,0 & 33,6 & 50,0 \\
\hline 3 & Низький & 60,0 & 56,8 & 40,5 & 40,0 & 37,5 & 48,6 & 7,1 \\
\hline 4 & Всього & 100 & 100 & 100 & 100 & 100 & 100 & 100 \\
\hline
\end{tabular}

лення себе і ситуації.

На етапі констатувального експерименту ми виявили, що для 48,6\% майбутніх психологів характерний низький рівень розвитку рефлексивного компоненту СМЦ, середній рівень характерний для 33,6\% досліджуваних, високий рівень розвитку характерний для 17,8\% досліджуваних. Крім того, варто звернути увагу відмінності у показниках рефлексивного компоненту студентів психологів та практикуючих психологів (табл. 4).

Відмінність показників компонентів СМЦ майбутніх психологів і практикуючих психологів підтверджена також і методами математичної статистики. Зокрема, за допомогою t-критерію Ст'юдента для незалежних вибірок доведено, що існують відмінності у практикуючих психологів (U емп.=2299,5 при $\mathrm{p} \leq 0,01)$.

Як видно 3 таблиці 4, у студентівпсихологів різних курсів рефлексивний компонент СМЦ розвинений відносно слабко, оскільки тільки у 17,8\% досліджуваних даний компонент має високий рівень розвитку. Це можна пояснити тим, що дані досліджувані більшою мірою зосереджені на задоволенні власних особистісних потреб, інтересів, орієнтовані на досягнення результату, а не на його сенс, складністю у встановленні рефлексивної дистанції для переосмислення власної ціннісної системи. Крім того, велика кількість досліджуваних першокурсників та другокурсників 3 низьким рівнем розвитку рефлексивного компоненту $(60,0 \%$ і $56,8 \%)$ може бути 
обумовлена їх соціальною незрілістю.

Висновки з даного дослідження та перспективи подальших розвідок у даному напрямi. На основі результатів проведеного емпіричного дослідження складових компонентів СМЦ майбутніх психологів встановлено, що:

а) мотиваційно-потребовий компонент СМЦ у більшості майбутніх психологів має високий та середній рівні розвитку, що свідчить про прагнення досліджуваних до самоактуалізації, самовдосконалення, реалізації власного потенціалу у професійній діяльності. Водночас досить вагома частина досліджуваних (21,6\%) мають низький рівень розвитку даного компоненту, що означає невираженість потреби у самоактуалізації, натомість вираженими $€$ інші види потреб, не пов'язаних прямо із майбутньою професійною діяльністю;

б) когнітивний компонент СМЦ у досліджуваних розвинений на достатньому рівні: більша половина майбутніх психологів має середній та високий рівень розвитку даного компоненту. Майбутнім психологам властиве розуміння більшості моральних понять, сформованість моральних принципів, усвідомлення загальносуспільних моральних цінностей, їх значення для виконання психологом професійної діяльності, однак у них спостерігається розмитість образу власного морального ідеалу, їм складно розмежувати власні моральні цінності від загальносуспільних. Варто відмітити також, що дані досліджувані серед власних моральних цінностей називають такі, які не пов’язані з обраною професією: щастя, здоров’я, матеріальний добробут, сім'я. Цей факт ми пояснюємо в першу чергу віковими особливостями досліджуваних;

в) поведінковий компонент СМЦ майбутніх психологів розвинений досить слабко: для 41,0\% досліджуваних характерний низький рівень розвитку. Майбутні психологи мають низькі показники автономності, спонтанності, креативності: характеризуються низькою пізнавальною активністю, мають завищене прагнення до досягнень, часто демонструють стереотипність, негнучкість, нездатність відійти від зразка у вирішенні певних проблем, проявляють недовіру до людей, схильність ними маніпулювати, невпевненість у собі, тривожність, нездатність відстоювати власні переконання, залежні від думки оточуючих про них;

г) рефлексивний компонент СМЦ, порівняно 3 іншими компонентами, розвинений найслабше. Досліджувані характеризуються нездатністю встановити дистанцію стосовно самого себе, зосереджені зазвичай на самому собі, орієнтовані на досягнення результату, а не на його сенс, мають низький рівень здатності до аналізу, переосмислення себе і ситуації. Встановлено, що для більшості майбутніх психологів $є$ актуальною потреба у самоактуалізації, однак недостатній розвиток інших компонентів СМЦ свідчить про те, що досліджуваним складно побачити шляхи для задоволення даної потреби саме у контексті обра- 
ної професії.

Таким чином, як видно 3 отриманих результатів емпіричного дослідження, існують суттєві відмінності між показниками розвитку компонентів СМЦ майбутніх психологів та практикуючих психологів, особливо ця відмінність помітна у результатах когнітивного, поведінкового та рефлексивного компонентів. Це дає нам підстави для розробки програми розвитку даних компонентів СМЦ у майбутніх психологів, що сприятиме більш успішній їх професійній підготовці, особистісному зростанню.

\section{Перелік використаних джерел:}

1.Адлер A. Понять природу человека: Пер. Е.А. Цыпина. - СПб.: Академический проект, 1997.

2.Бех І.Д. Особистісно зорієнтоване виховання: Науково-метод. посіб. / І.Д. Бех. - К.: ІЗМН, 1998. - 204 с.

3.Эриксон Э. Психологический кризис развития в отрочестве и юности / Э. Эриксон // Подросток и семья: хрестоматия / [под ред. Д.Я. Райгородского]. - Самара: Издательский Дом БАХРАХ. - М., 2002.- 656 с.

4.Карпенко 3.С. Ціннісні виміри індивідуальної свідомості / 3.С. Карпенко // Методологічні і теоретичні проблеми психології: хрестоматія / упорядн. 3.С. Карпенко, І.М. Гоян. - Івано-Франківськ: Плай, 2000. - $128 \mathrm{c}$.

5.Леонтьев Д.А. Психология свободы: к постановке проблемы самодетерминации личности / Д.А. Леонтьев // Психологический журнал. - Том 21, №1. -2000 . - C.3-11.

6.Матласевич О.В. Християнські цінності як основа психологічної практики: Наукові записки. Серія «Психологія i педагогіка» Випуск 25 / О.В. Матласевич. - Острог, Національний університет
«Острозька академія», 2013. - С. 96-100.

7.Савчин M. B. Духовна парадигма психології: [монографія[ / Мирослав Савчин. - К. : Академвидав, 2013. $-252 \mathrm{c}$.

8.Фромм Э. Человек для самого себя. Введение в психологию этики / Э. Фромм // Фромм Э. Психоанализ и этика. - М., 1993. - С. 59-95.

9.Фурман А.А. Психологія особистості: ціннісноорієнтаційний вимір: [монографія] / А.А. Фурман. Одеса: ОНПУ; Тернопіль: ТНЕУ, 2016. - 312 с.

10.Rokeach M. The Nature of Human Values. N.Y., 1973.

\section{References (Transliteration):}

1.Adler A. Ponyat prirodu cheloveka: Per. E.A. Tsyipina. $\mathrm{SPb} .:$ Akademicheskiy proekt, 1997.

2.Bech I.D. Personally Oriented Education: Scientific Method. manual / I.Д. Bech - K .: IZMN, 1998. - 204 p.

3.Erikson E. Psihologicheskiy krizis razvitiya $\mathrm{v}$ otrochestve i yunosti / E. Erikson // Podrostok i semya: hrestomatiya / [pod red. D.Ya. Raygorodskogo]. - Samara: Izdatelskiy Dom BAHRAH. - M., 2002.- 656 s.

4.Karpenko Z.S. Valuable measurements of individual consciousness / Z.S. Karpenko // Methodological and theoretical problems of psychology: textbook / routine. Z.S. Karpenko, I.M. Goian - Ivano-Frankivsk: Play, 2000. - 128 p.

5.Leontiev D.A. The Psychology of Freedom: The Problem of Self-Determination of Personality / D.A. Leontiev // Psychological journal. - Volume 21, No. 1. - 2000. - p.311.

6.Matlasevich O.V. Christian values as the basis of psychological practice: Scientific notes. Series "Psychology and Pedagogy" Issue 25 / O.V. Matlasevich - Ostrog, National University of Ostroh Academy, 2013. - P. 96-100.

7.Savchin M.V. Spiritual paradigm of psychology: [monograph [/ Myroslav Savchin. - K.: Akademvidav, 2013. $-252 \mathrm{p}$.

8.Fromm E. Chelovek dlya samogo sebya. Vvedenie v psihologiyu etiki / E. Fromm // Fromm E. Psihoanaliz i etika. 
- M., 1993. - S. 59-95.

9. Furman A.A. PsihologIya osobistosti: tsinnisnoorientatsiyniy vimir: [monografiya] / A.A. Furman. - Odesa: ONPU; Ternopil: TNEU, 2016. - 312 s.

10. Rokeach M. The Nature of Human Values. N.Y., 1973.

\section{Pedorenko Valentyna}

Assistant of the Department of Psychology and Social Work of the Educational and Scientific Institute of Pedagogy, Psychology, training of specialists of higher qualification of Mykhaylo Kotsybynskiy Vinnytsia State Pedagogical University, Vinnytsia (Ukraine)

\section{PSYCHOLOGICAL FEATURES OF THE DEVELOPMENT OF COMPONENTS OF SOVEREIGN MORAL VALUES OF FUTURE PSYCHOLOGISTS}

\section{ABSTRACT}

The concept of definition of sovereign moral values of future psychologists as stable, personally notional, meaningful moral forms: examples, concepts, attitudes what give the person an opportunity to self-assess his or her own live and lives of other people are depicted in the article. The content of their structural components such as: motivation-need, cognitive, behavioral, reflexive are shown. The levels of their distinguishing of development what are based on the application of the expert estimation method are investigated. Quantitative and qualitative analysis of the results of the empirical research gives an opportunity to point out the high, medium and low levels of development of the structural components of the sovereign moral values of future psychologists. The author describes the manifestations of different levels of their development, as well as explores and analyzes the peculiarities of the development of components of the sovereign moral values of future psychologists of different courses of study and successful psychologists. The comparative analysis of the peculiarities of their development is made.

The author of the article exposes the content of the motivational-need component of the sovereign moral values of future psychologists, what requires the presence of person's needs, what determine certain motives (interests, desires) and stipulate specific goal of the development of stable, autonomous, independent moral values of the future psychologist. The content of the cognitive component consists of knowledge, the thoughts of a person about his or her own moral values, beliefs, their expediency and rationality. The behavioral component of the sovereign moral values of the psychologist implies the manifestation of stable, autonomous, independent of external circumstances of the moral values in all spheres of his life: manifestation of independence, freedom, ability to self-disclosure, constant work on oneself, search of ways for selfperfection and self-realization, protection of own honor, dignity, satisfaction of the activity what he or she engages in. The reflexive component implies awareness of the future psychologist how he or she is perceived and assessed by others, the ability to analyze, rethink their own moral knowledge, feelings, beliefs, ideals and behavior.

Key words: sovereign moral values, components of sovereign moral values, motivationalneed component, cognitive component, behavior- 
al component, reflexive component, desire for self-actualization, autonomy, creativity, spontaneity.

\section{Педоренко Валентина Николаевна}

Ассистент кафедры психологии и социальной работь Учебно-научного института педагогики, психологии, подготовки спеичалистов высшей квалификации Винницкого государственного педагогического университета имени Михаила Коцюбинского, г. Винница (Украина)

\section{ПСИХОЛОГИЧЕСКИЕ ОСОБЕННОСТИ РАЗВИТИЯ КОМПОНЕНТОВ СУВЕРЕННЫХ НРАВСТВЕННЫХ ЦЕННОСТЕЙ БУДУЩИХ ПСИХОЛОГОВ}

Аннотация. В статье раскрывается содержание понятия суверенных нравственных ценностей будущих психологов как устойчивых, личностно значимых, смысложизненных нравственных образований: образцов, понятий, установок, которые дают возможность человеку оценивать собственную жизнь и жизнь других людей, описано содержание их структурных компонентов: мотивационнопотребностного, когнитивного, поведенческого, рефлексивного. На основе применения метода экспертных оценок определены критерии выделения уровней их развития. Количественный и качественный анализ результатов эмпирического исследования позволил выделить высокий, средний и низкий уровни развития структурных компонентов суверенных нравственных ценностей будущих психологов. Автором описано проявления различных уровней их развития, а также исследованы и проанализированы особенности развития компо- нентов суверенных нравственных ценностей будущих психологов разных курсов и успешных практикующих психологов, сделан сравнительный анализ особенностей их развития.

Автором статьи раскрывается содержание мотивационно-потребностной компонента суверенных нравственных ценностей будущих психологов, предусматривающий наличие в личности потребностей, которые обусловливают определенные мотивы (интересы, желания), конкретную цель развития устойчивых, автономных, независимых нравственных ценностей будущего психолога; содержание когнитивного компонента заключается в наличии знаний, представлений человека о своих нравственных ценностях, убеждениях, их целесообразность и рациональность. Поведенческий компонент суверенных нравственных ценностей психолога предполагает проявление во всех сферах его жизнедеятельности устойчивых, автономных, независимых от внешних обстоятельств нравственных ценностей: проявление независимости, свободы, способность к самораскрытию, постоянная работа над самим собой, поиск путей для самосовершенствования и самореализации, защиту своей чести, достоинства, получение удовольствия от дела, которым занимается. Рефлексивный компонент предполагает осознание будущим психологом того, как его воспринимают и оценивают окружающие, способность анализировать, переосмысливать собственные нравственные знания, чувства, 
убеждения, идеалы, поведение.

Ключевые слова: суверенные нравственные ценности, компоненты суверенных нравственных ценностей, мотивационнопотребностной, когнитивный, поведенческий, рефлексивный компоненты, стремление к самоактуализации, автономность, креативность, спонтанность.

Дата отримання статті: 04.12.2017

Дата рекомендації до друку: 21.12.2017 